\title{
Interpreting Breast International Group (BIG) 1-98: a randomized, double-blind, phase III trial comparing letrozole and tamoxifen as adjuvant endocrine therapy for postmenopausal women with hormone receptor-positive, early breast
} cancer

\author{
Meredith M Regan*1,2, Karen N Price',3, Anita Giobbie-Hurder', Beat Thürlimann ${ }^{4}$ and Richard D Gelber ${ }^{1-3}$ for the \\ International Breast Cancer Study Group and BIG 1-98 Collaborative Group
}

\begin{abstract}
The Breast International Group (BIG) 1-98 study is a four-arm trial comparing 5 years of monotherapy with tamoxifen or with letrozole or with sequences of 2 years of one followed by 3 years of the other for postmenopausal women with endocrine-responsive early invasive breast cancer. From 1998 to 2003, BIG 1-98 enrolled 8,010 women. The enhanced design of the trial enabled two complementary analyses of efficacy and safety. Collection of tumor specimens further enabled treatment comparisons based on tumor biology. Reports of BIG 1-98 should be interpreted in relation to each individual patient as she weighs the costs and benefits of available treatments. ClinicalTrials.gov ID: NCT00004205.
\end{abstract}

\section{Introduction}

Reports of large trials of breast cancer confirm the value of aromatase inhibitors as adjuvant systemic therapy for postmenopausal women with endocrine-responsive early breast cancer [1-9]. The inclusion of an aromatase inhibitor in the adjuvant treatment program for this population has been recommended by both the American Society of

\footnotetext{
${ }^{*}$ Correspondence: mregan@jimmy.harvard.edu 'International Breast Cancer Study Group (IBCSG) Statistical Center, Department of Biostatistics and Computational Biology, Dana-Farber Cancer Institute, 450 Brookline Avenue, Boston, MA 02215, USA

Full list of author information is available at the end of the article
}

Clinical Oncology and St. Gallen guidelines [10,11]. Studies have shown that 5 years of adjuvant therapy with an aromatase inhibitor alone improved disease-free survival (DFS) and time to distant recurrence (TDR) in comparison with 5 years of tamoxifen in this population [1-3,12], and recently the Breast International Group (BIG) 1-98 trial showed improved overall survival (OS) with the aromatase inhibitor letrozole [13]. Other studies have shown that switching to an aromatase inhibitor after 2 years of tamoxifen improves outcome [4-8]. Results were confirmed in an overview analysis [9].

The BIG 1-98 study is a double-blind, four-arm trial comparing 5 years of monotherapy with tamoxifen or with letrozole or with sequences of 2 years of one of these agents followed by 3 years of the other (Figure 1). Centers participated in one of two randomization options (twoarm or four-arm). Between 1998 and 2003, 8,010 patients were enrolled. The trial is designed to answer two questions concerning how best to use endocrine agents for the treatment of early breast cancer in postmenopausal women with hormone receptor-positive tumors, the first to compare letrozole monotherapy with tamoxifen monotherapy and the second to determine the benefit of letrozole in sequence with tamoxifen. Table 1 presents a summary of the study subpopulations contributing to various data analyses of efficacy questions. In BIG 1-98, the primary endpoint is DFS, defined as the time from random assignment to the earliest time of invasive recurrence in local, regional, or distant sites; a new invasive breast cancer in the contralateral breast; any second (non-breast) malignancy; or death from any cause. Secondary outcomes are OS, TDR, and safety $[14,15]$. 


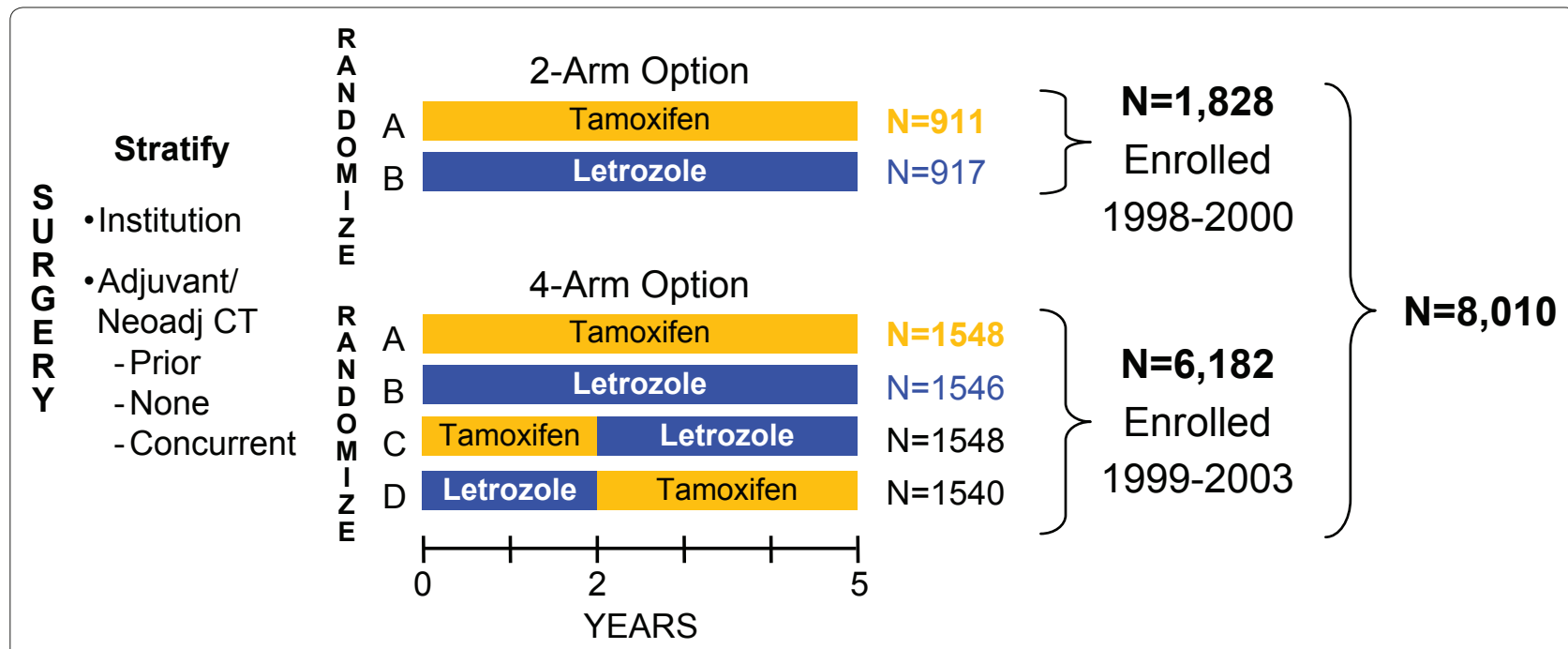

Figure 1. Design of the Breast International Group 1-98 trial. The design allows both head-to-head comparison of letrozole monotherapy versus tamoxifen monotherapy (4,922 patients) and assessment of the role of sequential endocrine treatments (6,182 patients). Neoadj CT, neoadjuvant chemotherapy.

Table 1. Summary of study populations in the Breast International Group 1-98 trial

\begin{tabular}{lcll}
\hline Population & $\begin{array}{c}\text { Number of } \\
\text { patients }\end{array}$ & Comments \\
\hline Intention-to-treat population & 8,010 & Eighteen randomly assigned patients withdrew consent to participate before starting treatment. \\
Two-arm randomization option & 1,828 & \\
Four-arm randomization option & 6,182 & \\
Primary core analysis population & 8,010 & Follow-up for two sequential treatment groups is censored at 2 years (time of treatment switch). \\
Monotherapy population & 4,922 & Patients were randomly assigned to receive 5 years of tamoxifen alone or letrozole alone. \\
$\quad$ Two-arm randomization option & 1,828 & \\
Four-arm randomization option & 3,094 & \\
Sequential treatment analysis population & $6,182 \quad$ Patients in the intention-to-treat population enrolled in the four-arm randomization option. \\
\hline
\end{tabular}

Patients were seen for follow-up at clinic visits every 6 months during treatment to gather general safety data, to document predefined toxicity data, and to receive a new supply of study medications. Survival, disease status, and cardiac, bone, and endometrial adverse events (AEs) were reported every 6 months for 5 years from random assignment and were followed by yearly reports after 5 years.

Various aspects of the results of BIG 1-98 have been published in separate papers in the past 5 years. The purpose of the present review is to bring the various results together in one place to give an overall interpretation of their significance for science and patient care.

\section{Letrozole versus tamoxifen}

The first report of the results of the BIG 1-98 trial was based on the primary core analysis, which was published in 2005 [1]. This analysis included all 8,010 patients but did not include any events after the first 2 years (the time of the switch) for patients in the two sequential arms. The results of the primary core analysis showed that letrozole improved DFS and TDR in comparison with tamoxifen alone. After a median follow-up of 25.8 months, 5-year DFS estimates were $84.0 \%$ and $81.4 \%$, respectively. As compared with tamoxifen, letrozole significantly reduced the risk of a DFS event (hazard ratio $(\mathrm{HR})=0.81,95 \%$ confidence interval $(\mathrm{CI}) 0.70$ to $0.93 ; P=0.003)$ and the risk of distant recurrence $(\mathrm{HR}=0.73,95 \% \mathrm{CI} 0.60$ to 0.88 ; $P=0.001)$.

For a report early in follow-up (when most of the observed events occurred within the first 2 years), the primary core analysis was appropriate, but for future updates, which are influenced substantially by events beyond 2 years, only those patients randomly assigned to the monotherapy arms (4,922 patients from both twoarm and four-arm options) are included in the head-tohead comparison of 5 years of letrozole versus tamoxifen $[2,13,14]$. The first results of the trial restricted to patients in the two monotherapy groups were published in 2007 [2]. At a median follow-up time of 51 months, results confirmed the earlier report, showing improved DFS (5-year DFS rates of $84.0 \%$ and $81.1 \%$ for letrozole and 
tamoxifen, respectively) ( $\mathrm{HR}=0.82,95 \% \mathrm{CI} 0.71$ to 0.95 ; $P=0.007)$ and improved TDR $(\mathrm{HR}=0.81,95 \% \mathrm{CI} 0.67$ to $0.98 ; P=0.03)$ with letrozole compared with tamoxifen. The monotherapy comparison was updated in 2010, after all patients had completed 5 years of trial treatment [13], and is discussed below.

\section{Selective crossover on the tamoxifen monotherapy arm}

In 2005, the presentation of the finding that letrozole significantly reduced both distant recurrences and DFS events compared with tamoxifen led to the decision to inform patients in the tamoxifen monotherapy group of their treatment assignment. 'Selective crossover' in this trial refers to the act of choosing to switch from tamoxifen monotherapy to letrozole prior to completion of 5 years of tamoxifen, after the results were known in 2005. While selective crossover is often in the best interest of patients, it complicates later trial analyses with further patient follow-up because the randomized, blinded trial design is compromised. Through a protocol amendment, women who were randomly assigned to tamoxifen alone and who were disease-free could receive letrozole. Of 2,459 patients in the tamoxifen-alone treatment arm, 619 (25.2\%) selectively crossed over to letrozole. The crossing over of $25 \%$ of patients from the less effective to the more effective regimen called into question whether the intention-to-treat (ITT) analysis, which ignores the crossover, will give the most clinically relevant updated estimate of the relative treatment effect.

Selective crossover represents a special case of nonadherence to a randomized treatment following the report of positive trial results. Specifically, control group patients are offered and accept the opportunity to cross over to the experimental treatment. Selective crossover is distinct from a protocol-defined treatment switch or ad hoc non-adherence to a random assignment because the crossover is motivated by randomized evidence that the experimental treatment is more effective. Thus, the ITT control group subject to selective crossover is likely to have a better outcome than if the control group had continued to receive the randomized treatment. Selective crossover disturbs the randomized comparison in updated analyses performed subsequent to first results and therefore particularly impacts the OS results, which require longer follow-up.

With selective crossover and further follow-up, the treatment received by patients in the tamoxifen control arm in BIG 1-98 becomes a mix of the control and experimental treatments. With the potential for selection bias among the patients who decide to cross over, the benefits of random assignment erode and the trial becomes a hybrid of a randomized trial and observational study. For a randomized clinical trial, the ITT analysis is the 'gold standard' analytic approach designed to control bias. However, external evidence from a meta-analysis of similar trials [9] shows that the estimated outcomes of the tamoxifen arm in the ITT analysis are likely to be better than if the trial had not been amended and all patients randomly assigned to tamoxifen continued to receive the drug for 5 years. As the selective crossover transforms the randomized trial toward an observational study, established modeling methods to address issues of bias due to treatment selection are needed. For the BIG 1-98 study, the methodology called inverse probability of censoring weighted (IPCW) analysis is used to clarify the clinical benefit of letrozole compared with tamoxifen [13]. The IPCW analysis estimates the clinical benefit of letrozole versus tamoxifen which would have been observed had there been no selective crossover in the trial. An editorial accompanying the manuscript confirmed the appropriateness of this method and discussed the interpretation of the IPCW results in the trial specifically and cancer trials more broadly [16].

\section{Monotherapy comparison using inverse probability of censoring weighted analysis}

IPCW is a well-established approach in randomized and observational studies to overcome selection biases. The method is one of several approaches to causal inference and analyzes only the available data under conditions of 'informative' missing data. Specifically, we employed IPCW Cox modeling [17]. In the setting of selective crossover, IPCW modeling artificially creates a scenario of 'missing' follow-up data by censoring the follow-up of each woman at the time she crossed over ('informative' censoring). However, the truncated follow-up is 'recreated' by applying weighting to the follow-up of women who have similar demographic and disease characteristics and who did not cross over. In this way, the follow-up of women who remain on tamoxifen accounts not only for themselves in the analysis but also for comparable women whose experience remaining on tamoxifen cannot be observed, because they selectively changed treatments.

In the IPCW monotherapy analysis, we analyzed the data set of the protocol-specified update at 10 years after trial initiation [12] and took into consideration the selective crossover. After follow-up was truncated, the median follow-up was reduced to 74 months (IPCW) from 76 months (ITT).

Weighted Cox models, using IPCW, estimated a statistically significant, $18 \%$ reduction in the hazard of an OS event with letrozole treatment $(\mathrm{HR}=0.82,95 \% \mathrm{CI}$ 0.70 to 0.95 ). IPCW estimates of 5 -year OS were $91.8 \%$ and $90.4 \%$ for letrozole and tamoxifen, respectively. The IPCW HRs of DFS and TDR events were 0.83 (95\% CI 0.74 to 0.94 ) and 0.80 (95\% CI 0.67 to 0.94 ), respectively (Figure 2). The results show that adjuvant treatment with 




letrozole, compared with tamoxifen, significantly reduces the risk of death, the risk of recurrent disease, and the risk of recurrence at distant sites in postmenopausal women with hormone receptor-positive breast cancer. The OS results were consistent in most subgroups (Figure 2).

\section{Sequential treatment comparisons}

The analysis of the sequential treatments was limited to the 6,182 patients entered into the four-arm option (Figure 1). The sequential treatment analysis was published in 2009 [12], with emphasis on comparing the two letrozole-containing sequential regimens with letrozole monotherapy from the time of random assignment; the three letrozole-containing regimens had remained blinded. The tamoxifen monotherapy regimen was already shown to be less effective than letrozole, had been unblinded, and therefore was not included in the efficacy comparisons. Tamoxifen was, however, included in AE comparisons with the other three regimens.

At a median follow-up of 71 months from random assignment, neither tamoxifen followed by letrozole 


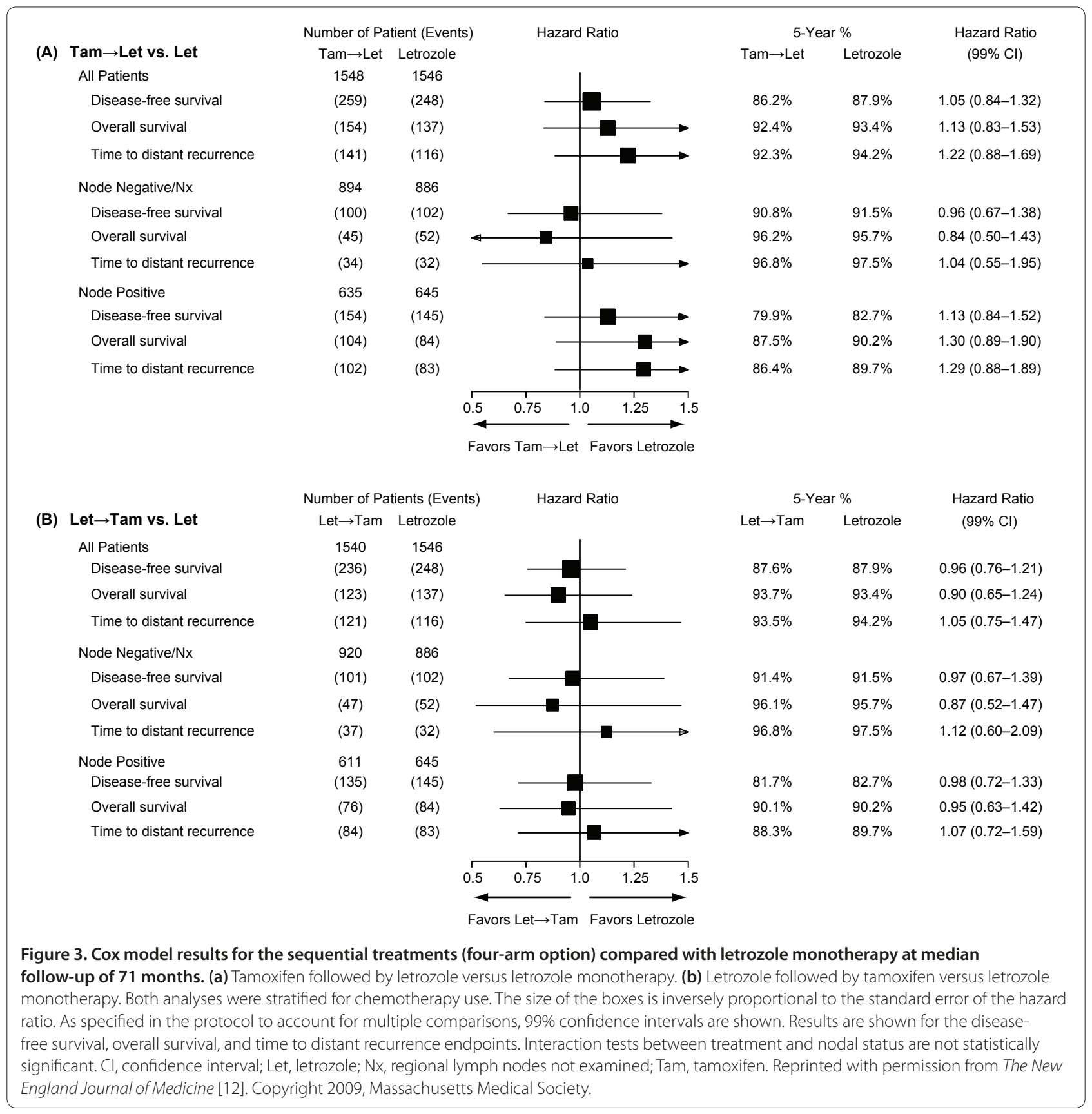

$(\mathrm{HR}=1.05,99 \%$ CI 0.84 to 1.32$)$ nor letrozole followed by tamoxifen ( $\mathrm{HR}=0.96,99 \% \mathrm{CI} 0.76$ to 1.21 ) significantly improved DFS compared with letrozole monotherapy (Figure 3). Women assigned tamoxifen followed by letrozole had a greater incidence of early relapses than those assigned letrozole monotherapy. Sequential treatment regimens with letrozole and tamoxifen did not improve DFS compared with letrozole monotherapy (Figure 3). The estimated 5-year DFS percentages for the three letrozole-containing regimens of the sequential treatment analysis population are $87.9 \%, 87.6 \%$, and $86.2 \%$ for letrozole monotherapy, letrozole followed by tamoxifen, and tamoxifen followed by letrozole groups, respectively. These differences are not statistically significant.

\section{Translational research}

As early as 2006, the BIG 1-98 database was used to identify prognostic factors for breast cancer relapse. Using the primary core analysis database [1] and Cox proportional hazards regression, we analyzed all eligible patients treated on BIG 1-98 and evaluated factors predictive of early relapse (within 2 years from random 
assignment). Locally determined predictive factors for early relapse were node positivity, negative or missing estrogen receptor (ER) or progesterone receptor (PgR), high tumor grade, HER2 overexpression/amplification, large tumor size, treatment with tamoxifen monotherapy, and peritumoral vascular invasion. Upfront letrozole resulted in significantly fewer early relapses than tamoxifen, even after adjusting for significant prognostic factors. These early findings [18] helped set the stage for future translational research.

In 2005, the International Breast Cancer Study Group (IBCSG) Central Pathology Laboratory, recognizing the importance of accurate assessment of the molecular targets that might predict the better treatment, began collecting formalin-fixed, paraffin-embedded tumor blocks or, if these were not available, unstained slides for the assessment of ER, PgR, HER2, and Ki-67 labeling index (LI). The material was reviewed for histopathological features and expression of tumor biomarkers without knowledge of patients' treatment assignment or outcome. The first reports using these assessments focused on comparing letrozole and tamoxifen monotherapy by using the database reported at median followup of 51 months [2].

\section{Role of accurate assessment of steroid hormone receptor status}

The first translational analysis focused on the primary target for endocrine treatment, steroid hormone receptors. To be enrolled in BIG 1-98, the primary tumor had to be determined by local pathologists prior to random assignment to be positive for ER or PgR.

The impact and importance of central assessment of ER and $\operatorname{PgR}$ for patients receiving monotherapy were reported in 2007 [19]. Local assessment for eligibility classified $99.9 \%$ of enrolled patients as having hormone receptor-positive disease. Central assessment using immunohistochemistry (IHC) of 6,291 tumors classified 97.0\% as positive (ER or PgR levels (or both) of at least $10 \%)$. Monotherapy cohort patients whose tumors were classified locally as hormone receptor-positive and reclassified as hormone receptor-negative by central review had worse outcomes, with estimated 65\% 3-year DFS compared with $91 \%$ among patients whose tumors were classified concordantly as positive (Figure 4).

\section{Development of the Subpopulation Treatment Effect Pattern Plot}

A key analysis tool for determining the importance of these continuous-value biomarkers (such as level of ER staining) for determining treatment effectiveness is the Subpopulation Treatment Effect Pattern Plot (STEPP) [20]. STEPP was specifically developed for exploring patterns of treatment outcome differences across

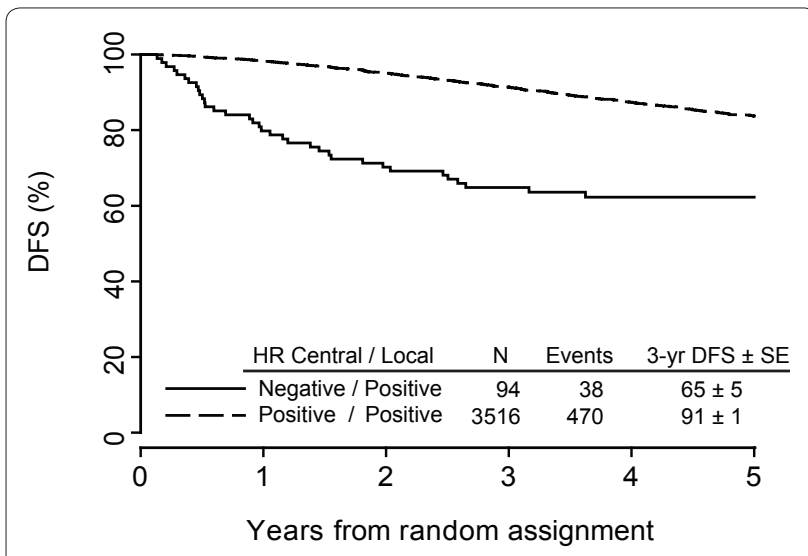

Figure 4. Disease-free survival according to central and local classification of hormone receptor status. Kaplan-Meier estimates at a median follow-up of 4 years for 3,610 patients on the monotherapy arms of Breast International Group 1-98 with adequate tumor material for central assessment of hormone receptors are shown. The two receptors are combined to define an overall assessment of hormone receptor status. Positive refers to estrogen receptor-positive or progesterone receptor-positive or both, and negative indicates that both are negative. DFS, disease-free survival; $\mathrm{HR}$, hormone receptor; SE, standard error. Reprinted with permission from the Journal of Clinical Oncology [19]. Copyright 2007, American Society of Clinical Oncology.

subpopulations of patients defined according to overlapping intervals of the biomarker values. The STEPP graphical presentation provides an overview of outcomes according to all values of a biomarker and can be used in addition to comparing treatments within subgroups based on established or arbitrarily defined cutpoints (Figures 5 and 6).

\section{PgR and HER2 as predictive factors for letrozole versus tamoxifen monotherapy}

Central assessment of ER, PgR, and HER2 status was evaluable for 3,650 patients (74\%) from the monotherapy arms $[19,21]$. Note that these patients were treated prior to the availability of trastuzumab for HER2-positive tumors. Tumors were considered HER2-positive if amplified by fluorescence in situ hybridization (FISH) (geneto-chromosome 17 ratio of at least 2.0) or if staining intensity was $3+$ by IHC (circumferential and intense membrane staining of greater than $10 \%$ invasive tumor cells) in the few tumors with unevaluable/unavailable FISH results. In tumors confirmed to express ER, 10\% had no PgR expression and $7 \%$ were HER2-positive. Alhough absence of PgR expression and HER2 positivity were each associated with poorer DFS, there remained a DFS advantage of letrozole for 5 years over tamoxifen for 5 years irrespective of PgR or HER2 status [19,21]. Accordingly, PgR or HER2 alone or together should not be used as discriminators in selecting initial adjuvant endocrine 







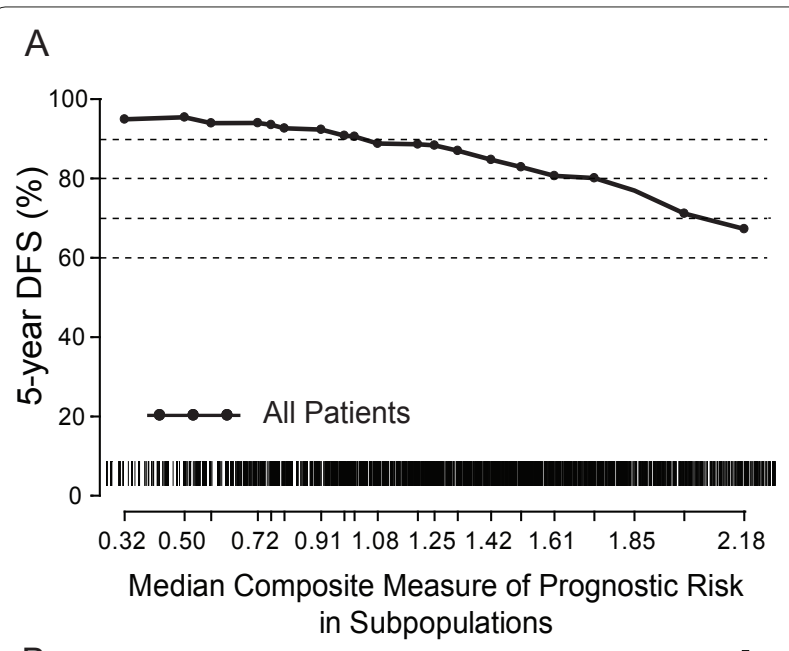

B

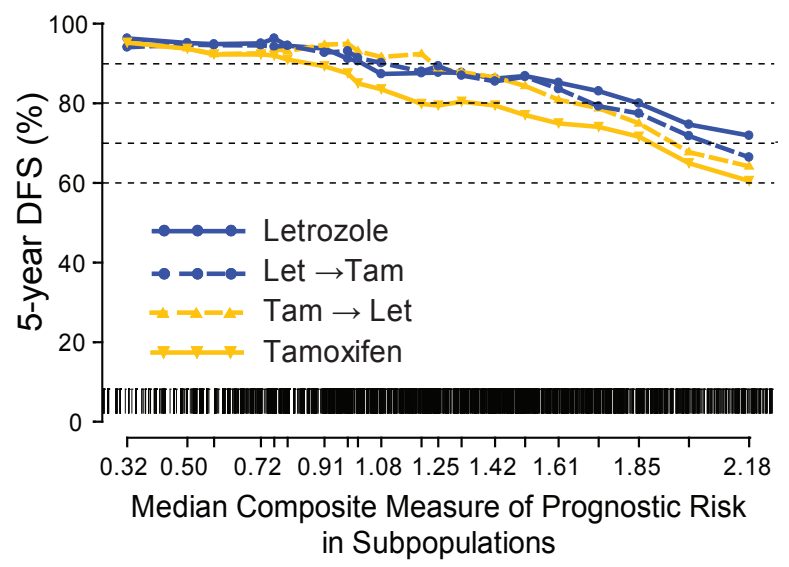

Figure 6. STEPP analysis of 5-year disease-free survival according to level of composite measure of prognostic risk. Plots include the 5,177 assessable patients enrolled in the four-arm option at a median follow-up of 71 months. (a) Treatment groups combined and (b) according to randomized treatment group. Rug plots along the $x$-axis display the distribution of individual values. DFS, disease-free survival; Let, letrozole; STEPP, Subpopulation Treatment Effect Pattern Plot; Tam, tamoxifen. Reprinted with permission from Annals of Oncology [23]. Copyright 2011, Oxford University Press.

therapy for postmenopausal women with endocrineresponsive early breast cancer.

\section{Ki-67 labeling index as predictive factor for letrozole versus tamoxifen monotherapy}

Among patients in the monotherapy analysis, 2,685 had primary tumor material available for central pathology assessment of Ki-67 LI by IHC and had tumors confirmed to express ER after central review [22]. Higher values of Ki-67 LI were associated with poorer DFS, and there may be an interaction of Ki-67 LI with treatment as the magnitude of the treatment benefit for letrozole versus tamoxifen monotherapy was observed to be greater among patients with high-tumor Ki-67 LI than among those with low-tumor Ki-67 LI. In BIG 1-98, Ki-67 LI is a prognostic factor, and high Ki-67 LI levels may identify a patient group that particularly benefits from initial letrozole adjuvant therapy.

\section{Composite risk assessment in the sequential treatment population}

When the sequential treatment analysis was published [12], the IBCSG had collected and assessed additional tumor material for the four biomarkers. The investigation of the role of these biomarkers for the sequential treatments (four-arm option) (Figure 1) included 5,177 patients (84\%) with centrally confirmed ER expression and other biomarkers available. This analysis was based on the database used for the primary outcome of the sequential treatments at median follow-up of 71 months [12]. This analysis also accounted for selective crossover.

We assessed whether centrally determined ER, PgR, and HER2 overexpression/amplification and Ki-67 LI, alone or in combination with other prognostic features, predicted the magnitude of letrozole effectiveness compared with either sequence or tamoxifen monotherapy [23]. One motivation for this approach was that, despite a lack of data, a majority of the 2009 St. Gallen panelists preferred an initial aromatase inhibitor 'particularly for patients at higher risk' [11]. Second, in some settings, the cost and (for some patients) the side effects of aromatase inhibitor therapy make tamoxifen the preferable treatment. We therefore attempted to examine whether clinical and pathological features can identify patient groups for whom it is more or less important that a 5 -year program include only or some aromatase inhibitor therapy.

Individually, none of the biomarkers significantly predicted differential treatment effects among the treatment groups (Figure 5). STEPP analysis of a composite measure of prognostic risk - which was based on an individual's number of involved lymph nodes, tumor grade, tumor size, presence of peritumoral vascular invasion as determined by local pathology, plus age and the four centrally assessed tumor biomarkers - revealed three patterns of treatment effects (Figure 6b). Patients at highest risk did best when treated with 5 years of letrozole; any of the three letrozole-containing regimens was acceptable for those patients in an intermediate-risk range; whereas patients at lowest risk did similarly well with letrozole monotherapy, a sequence of letrozole and tamoxifen, or tamoxifen monotherapy. Thus, in BIG 1-98, we confirmed that the principle of composite assessment of risk, analogous to the clinical practice of integrating multiple risk factors when physicians and patients are deciding on the best adjuvant endocrine treatment for the individual patient, informs treatment selection better 
than individual biomarkers and supports the choice of 5 years of letrozole for patients at the highest risk for recurrence.

\section{Future translational research}

With the collection of over 5,000 tumor blocks, the IBCSG Central Pathology Office was able to create tissue micoarrays to facilitate future research. Recent improvements in the extraction of DNA and RNA from formalinfixed, paraffin-embedded tumor blocks enable the investigation of molecular features of the tumor and these features may predict a better patient outcome from endocrine therapy strategies. Plans are under way to investigate disease-related features, such as polymorphisms in or gene expression of ER-related genes, and patient-related features, such as polymorphisms in genes related to tamoxifen or aromatase inhibitor metabolism.

The first of these investigations evaluated the clinical relevance of cytochrome P450 2D6 (CYP2D6). Polymorphisms leading to reduced CYP2D6 enzyme activity may result in lower plasma concentrations of tamoxifen's clinically active metabolite endoxifen, and this may in turn adversely impact the efficacy of tamoxifen. Because of conflicting results of several small studies that investigated the relation of CYP2D6 polymorphisms with clinical outcomes, whether polymorphisms that result in phenotypes of reduced enzyme activity are in fact associated with poorer disease control among tamoxifentreated patients is not clear. Results based on genotyping CYP2D6 polymorphisms among almost 5,000 BIG 1-98 patients were presented at the San Antonio Breast Cancer Symposium in December 2010 [24] and a manuscript is in preparation.

\section{Side effects}

For patients undergoing study drug administration, AEs were recorded at each 6-month follow-up visit by using check boxes on the case report forms. Severity was classified according to National Cancer Institute Common Toxicity Criteria Version 2.0. The relationship of the AE to study treatment was assessed by the local investigator. Targeted AEs that were explicitly collected were cardiovascular events (that is, myocardial infarction, cerebrovascular accident, transient ischemic attack, angina requiring percutaneous luminal coronary angioplasty or coronary artery bypass graft, thromboembolic event, hypercholesterolemia (cholesterol values reported, mostly non-fasting), and 'other'), bone fractures, vaginal bleeding, endometrial pathology, nausea, vomiting, hot flushes, night sweats, and events leading to therapy discontinuation. Other cardiovascular AEs were collected by using an open-text comment field for specification by the investigator. Open-text fields were coded according to the Medical Dictionary for Regulatory Activities (MedDRA), and MedDRA preferred term [25] codes were further grouped into categories by IBCSG oncologists.

Senior oncologists at the IBCSG Coordinating Center, who were blinded to treatment assignment, reviewed all grade 3,4 , or 5 cardiovascular AEs; other grade 3 to 5 AEs whose causes were unclear; and all deaths occurring prior to a DFS event. Pre-existing cardiovascular morbidities reported at the time of enrollment were also medically reviewed. A report of the cardiovascular side effects following this extensive review was published in 2007, documenting a low overall cardiovascular AE incidence that differed between monotherapy treatment arms [26]. The incidence of hypertension or cerebrovascular events was similar as was the overall incidence of cardiac AEs, although there were more grade 3 to 5 cardiac AEs on letrozole; this excess was only partially attributable to prior hypercholesterolemia. There were more overall and grade 3 to 5 thromboembolic AEs on tamoxifen. The incidence of AEs has been updated through a median follow-up of 76 months (Figure 7).

In addition, several focused reports on the safety of letrozole and tamoxifen in BIG 1-98, including bone events [27] in all patients and AEs in elderly patients [28], have been published. Consistent with other reports of aromatase inhibitors, the incidence of bone fractures was higher among patients treated with letrozole versus tamoxifen. The wrist was the most common site of fracture in both treatment groups. Risk factors for bone fractures during treatment included age, smoking history, osteoporosis at baseline, previous bone fracture, and previous hormone replacement therapy. Efficacy results were similar for all age groups, including the $6 \%$ of 'elderly' patients (over age 75 years) who were less likely to complete 5 years of either trial treatment. Incidence of bone fractures did not differ by age. Among elderly patients, letrozole had a significantly higher incidence of any grade 3 to 5 protocol-specified non-fracture $\mathrm{AE}$ compared with tamoxifen, but differences were not significant for thromboembolic or cardiac AEs. On the basis of a small number of patients older than 75 years, age per se should not be the only consideration for the choice of adjuvant endocrine therapy.

Detailed AE results comparing the entire 5-year treatment period for all four treatments [12] and for the monotherapy cohort [13] have been published. As previously reported, patients on tamoxifen experienced greater incidences of thromboembolic events, vaginal bleeding, hot flushes, and night sweats. Patients on letrozole experienced greater incidences of vaginal dryness, bone fractures, osteoporosis, and arthralgia/ myalgia (Figure 7a) and higher-grade cardiac events (Figure $7 \mathrm{~b}$ ). It is important to note that these analyses present the incidence of AEs for one regimen (letrozole) compared with the other (tamoxifen), and it is possible 


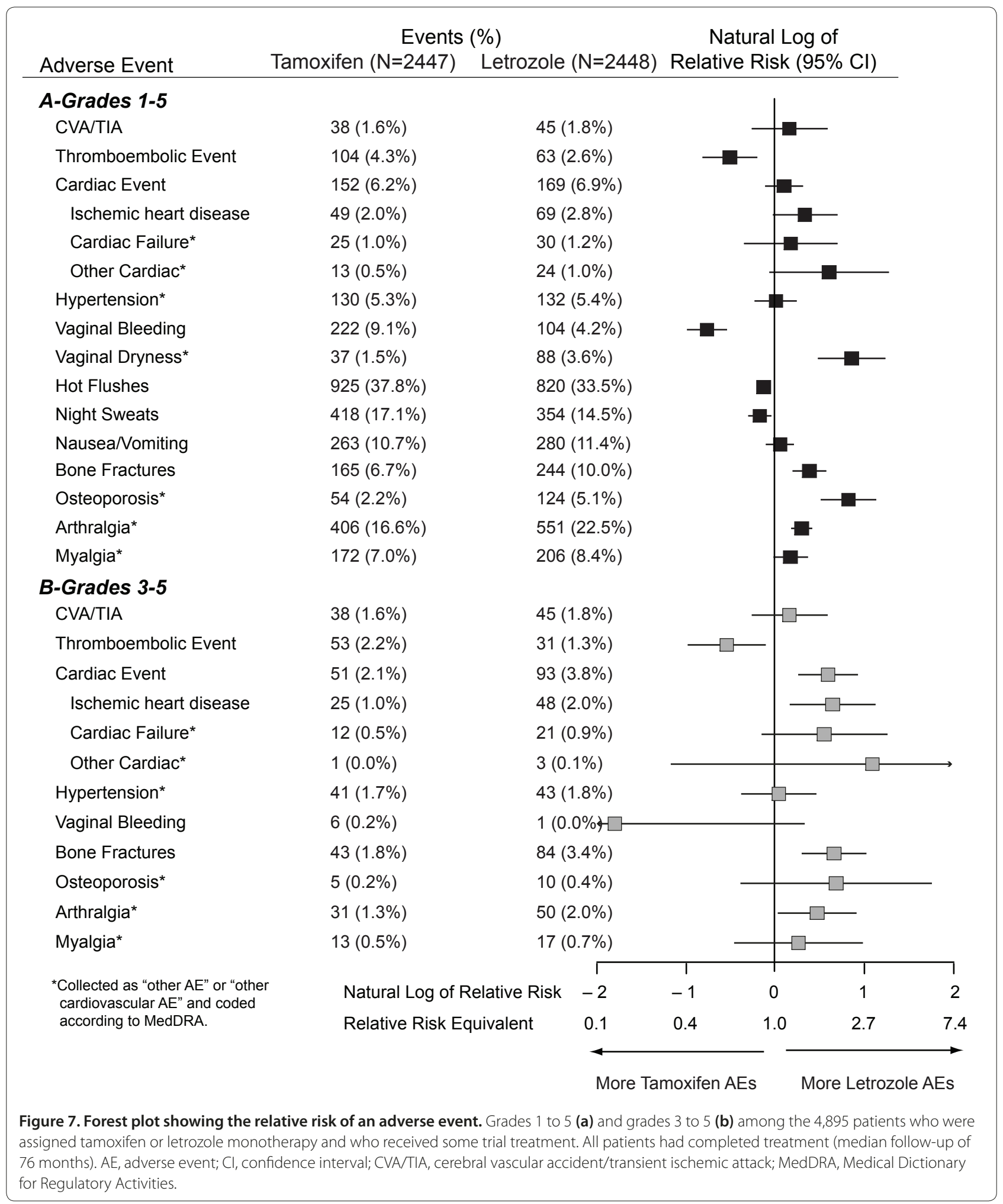

that tamoxifen in particular offers protection from cardiac or bone events $[29,30]$. The incidences of the AEs occurring in the sequential arms generally show results similar to those of the monotherapies during the time the patient was on the individual agents (that is, first 2 years or last 3 years) [12]. Figure 8 shows Kaplan-Meier 


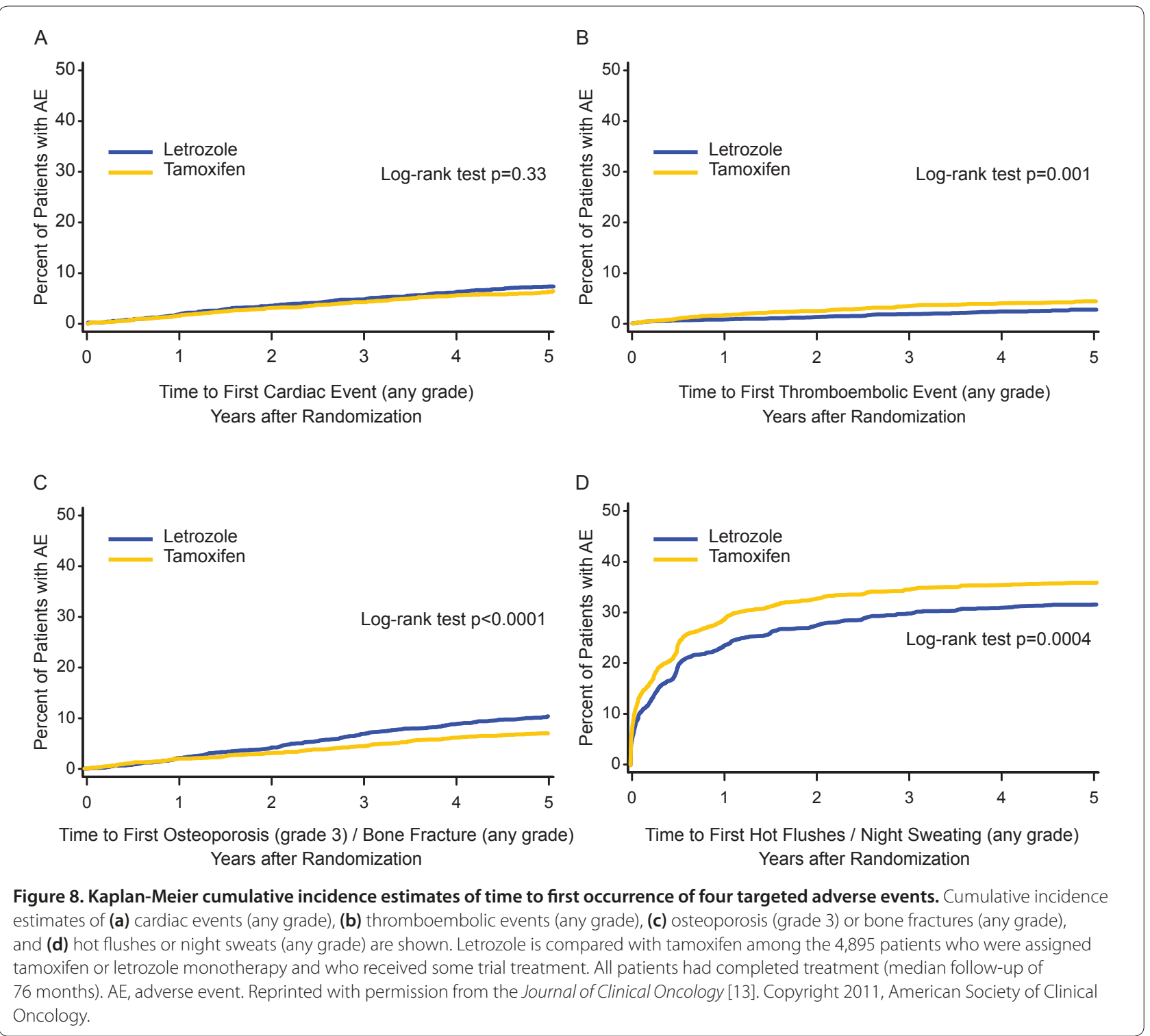

cumulative incidence estimates of time to the first occurrence of four targeted AEs. The incidence rates of cardiac events, thromboembolic events, and bone fractures or severe osteoporosis (Figure 8a-c) were relatively constant throughout follow-up. In contrast, $24 \%$ of women taking letrozole and $29 \%$ taking tamoxifen reported hot flushes/night sweating within the first year of therapy, with the incidence rates gradually decreasing over time (Figure 8d) [12].

\section{Cognitive function substudy}

In this substudy, cognitive function assessments were completed at the end of treatment (5 years) and about 1 year later (6 years). The 5-year analysis showed that cognitive function was significantly better among the patients who were receiving letrozole at the end of the 5-year treatment period in comparison with those receiving tamoxifen [31]. A second analysis comparing the 5-year assessments of cognitive function with those collected about 1 year later showed a significant improvement in cognitive function following completion of endocrine therapy for both treatment regimens; the magnitude of improvement was not significantly different between treatments [32].

\section{Discussion}

The BIG 1-98 trial was designed to compare 5 years of tamoxifen with 5 years of the aromatase inhibitor letrozole and to compare the strategy of the sequential treatments with the monotherapy approach. Twelve years after the first patient was entered, these goals have been met. During these 12 years, evolving data from other 
trials and the selective crossover of one quarter of the tamoxifen-treated patients to a more effective treatment in this trial led to the adaptation of analysis plans to present the most accurate and clinically useful long-term results to the oncology community.

Although all of the patients have completed protocol treatment, BIG 1-98 continues to provide useful information beyond the primary questions of efficacy. The translational reports on known biomarkers and the composite assessment obtained by putting the available tumor characteristics together to assess the risk of recurrence provide a basis on which to make informed patient treatment selection decisions. Future translational research will assess, for example, outcome according to CYP2D6, further clarifying individual patient differences that may be used to make treatment decisions. The detailed safety data from this study also provide information that can be used to assist in treatment selection. These data are reassuring for the average patient, and certain patient co-morbidities and conditions should be considered in weighing the treatment options.

\section{Conclusions}

In all reports of this trial, the authors have attempted to present a clear interpretation of the treatment comparisons for both the average and the individual patient. Reports to date have presented the most clinically meaningful analyses and interpretations. The enhanced study design has enabled the presentation of two research questions from a single trial, thus saving time and money. On average, letrozole improves DFS, TDR, and OS in comparison with tamoxifen. Neither sequence of treatments improves results over letrozole monotherapy. However, there may be groups of patients (for example, those at low or intermediate risk) for whom tamoxifen or a sequence of the two agents represents a reasonable choice.

There is no single interpretation of this trial, but for postmenopausal women with endocrine-responsive early breast cancer, BIG 1-98 results can be used to weigh the risks and benefits of the various treatment options in terms of efficacy in tumor-defined subgroups, AEs observed among 8,000 women, and tumor biology not yet determined.

This article is part of a review series on Controversies in Al therapy, edited by Lewis Chodosh. Other articles in the series can be found online at http://breast-cancer-research.com/series/Al_controversies.

\section{Abbreviations}

$\mathrm{AE}$, adverse event; BIG, Breast International Group; Cl, confidence interval; CYP2D6, cytochrome P450 2D6; DFS, disease-free survival; ER, estrogen receptor; FISH, fluorescence in situ hybridization; $H R$, hazard ratio; IBCSG, International Breast Cancer Study Group; IHC, immunohistochemistry; IPCW, inverse probability of censoring weighted; ITT, intention-to-treat; LI, labeling index; MedDRA, Medical Dictionary for Regulatory Activities; OS, overall survival; PgR, progesterone receptor; STEPP, Subpopulation Treatment Effect Pattern Plot; TDR, time to distant recurrence.

\section{Competing interests}

Novartis (Basel, Switzerland), as the sponsor of the BIG 1-98 trial, contributed funds to the IBCSG to conduct the trial and retrospective tissue collection. Some of these funds were used to partially finance the IBCSG Statistical Center (MMR, $\mathrm{AG}-\mathrm{H}, \mathrm{KNP}$, and RDG) and participating centers (BT). BT owns stock in Novartis.

\section{Author information}

MMR is IBCSG group statistician. KNP is IBCSG director of scientific administration. $\mathrm{AG}-\mathrm{H}$ is $\mathrm{BIG} 1-98$ trial statistician. $\mathrm{BT}$ is $\mathrm{BIG} 1-98$ study chair. RDG is IBCSG statistical and data management center director.

\section{Acknowledgments}

The IBCSG Statistical Center is partially supported by US National Cancer Institute grant CA-75362. The BIG 1-98 trial is financed by Novartis and is coordinated by the IBCSG. Support for the IBCSG was provided from the Swedish Cancer Society, The Cancer Council Australia, Australian New Zealand Breast Cancer Trials Group, Frontier Science and Technology Research Foundation, Swiss Group for Clinical Cancer Research (SAKK), Cancer Research Switzerland/Oncosuisse, and the Foundation for Clinical Cancer Research of Eastern Switzerland (OSKK). Translational research was partially funded by Susan G. Komen for the Cure Promise Grant KG080081.

\section{Author details}

'International Breast Cancer Study Group (IBCSG) Statistical Center, Department of Biostatistics and Computational Biology, Dana-Farber Cancer Institute, 450 Brookline Avenue, Boston, MA 02215, USA. ${ }^{2}$ Harvard School of Public Health and Harvard Medical School, 25 Shattuck Street, Boston, MA 02115, USA. ${ }^{3}$ Frontier Science and Technology Research Foundation, 900 Commonwealth Avenue, Boston, MA 02215, USA. ${ }^{4}$ Breast Center, Kantonsspital, St. Gallen, Switzerland CH-9007, Swiss Group for Clinical Cancer Research (SAKK), Bern, Switzerland $\mathrm{CH}-3008$.

\section{Appendix}

Breast International Group (BIG) 1-98 Collaborative Group Participants Steering Committee: B. Thürlimann (Chair), S. Aebi, L. Blacher, A. S. Coates, T. Cufer, J. F. Forbes, R. D. Gelber, A. Giobbie-Hurder, A. Goldhirsch, A. Hiltbrunner, S. B. Holmberg, R. Maibach, A. Martoni, L. Mauriac, G. MacGrogan, H. T. Mouridsen, R. Paridaens, D. Phuong, K. N. Price, M. Rabaglio, B.B. Rasmussen, M.M. Regan, A. Santoro, I. E. Smith, A. Wardley, G. Viale. Novartis: H. A. ChaudriRoss, S. Segal, D. B. Evans.

International Breast Cancer Study Group (IBCSG) Foundation Council (members from 1998 to 2010): S. Aebi, A. S. Coates, M. Colleoni, J. P. Collins, H. Cortés Funes, R. D. Gelber, A. Goldhirsch, M. Green, A. Hiltbrunner, S. B. Holmberg, P. Karlsson, I Kössler, I. Láng, J. Lindtner, F Paganetti, M. de Stoppani, C.-M. Rudenstam, H.-J. Senn, R. Stahel, B. Thürlimann, A. Veronesi.

Coordinating Center (Berne, Switzerland): M. Castiglione (Chief Executive Officer 1998 to 2007), A. Hiltbrunner (Director), M. Rabaglio, G. Egli, H. Hawle, B. Cliffe, S. Ribeli-Hofmann, F. Munarini, R. Kammler, R. Studer, B. Ruepp, R. Maibach, N. Munarini.

Statistical Center (Dana-Farber Cancer Institute, Boston, MA, USA): R. D. Gelber (Director) , M.M. Regan (Group Statistician), K. N. Price (Director of Scientific Administration), A. Giobbie-Hurder (Trial Statistician), A. Keshaviah, H. Litman, Z. Sun, H. Huang, L. J. Somos, B. Timmers, L. Nickerson.

Data Management Center (Frontier Science \& Technology Research Foundation, Amherst, NY, USA): L. Blacher (Director of Data Management), T. Heckman Scolese (Coordinating Data Manager), M. Belisle, M. Caporale, J. Celano, L. Dalfonso, L. Dooley, S. Fischer, K. Galloway, J. Gould, R. Hinkle, M. Holody, G. Jones, R. Krall, S. Lippert, J. Meshulam, L. Mundy, A. Pavlov-Shapiro, K. Scott, M. Scott, S. Shepard, J. Swick, L. Uhteg, D. Weinbaum, C. Westby, T. Zielinski.

Central Pathology Review Office (University of Glasgow, Glasgow, UK): B. A. Gusterson, E. Mallon; (European Institute of Oncology, Division of Pathology, Milan, Italy): G. Viale, P. Dell'Orto, M. Mastropasqua, B. Del Curto.

Study Support (Novartis Corp., Basel, Switzerland): E. Waldie, I. van Hoomissen, M De Smet, U. Trostmann, W. Schmidt, A. Bolton, W. Hackl. 
BIG

\section{IBCSG}

Australian New Zealand Breast Cancer Trials Group (ANZ BCTG): R. D. Snyder, J. Chirgwin, J. F. Forbes, A. S. Coates, F. Boyle, D. Lindsay, D. Preece, J. Cowell, D. Talbot, A. Whipp.

Australia: The Cancer Council Victoria, Melbourne, VIC: F. Abell, R. Basser, R. Bell, B. Brady, D. Blakey, P. Briggs, I. Burns, P. Campbell, M. Chao, J. Chirgwin, B. Chua, K. Clarke, J. Collins, R. De Boer, J. C. Din, R. Doig, A. Dowling, R. Drummond, N. Efe, S. T. Fan, M. Francis, P. Francis, V. Ganju, P. Gibbs, G. Goss, M. Green, P. Gregory, J. Griffiths, I. Haines, M. Henderson, R. Holmes, P. James, J. Kiffler, M. Lehman, M. Leyden, L. Lim, G. Lindeman, R. Lynch, B. Mann, J. McKendrick, S. McLachlan, R. McLennan, G. Mitchell, S. Mitra, C. Murphy, I. Parker, K. Phillips, I. Porter, G. Richardson, J. Scarlet, S. Sewak, J. Shapiro, R. Snyder, R. Stanley, C. Steer, D. Stoney, A. Strickland, G. Toner, C. Underhill, K. White, M. White, A. Wirth, S. Wong; W P Holman Clinic, Launceston General Hospital, Launceston, Tasmania: D. Byram, I. Byard; Liverpool Hospital, Sydney, NSW: S. DellaFiorentina, A. Goldrick, E. Hovey, E. Moylan, E. Segelov; Mount Hospital, Perth, WA: A. Chan, M. Buck, D. Hastrich, D. Ingram, G. Van Hazel, P. Willsher; Nepean Cancer Care Centre, Sydney, NSW: N. Wilcken, C. Crombie; Calvary Mater Newcastle, Newcastle, NSW: J. F. Forbes, F. Abell, S. Ackland, A. Bonaventura, S. Cox, J. Denham, R. Gourlay, D. Jackson, R. Sillar, J. Stewart; Prince of Wales Hospital, Sydney, NSW: C. Lewis, B. Brigham, D. Goldstein, M. Friedlander: Princess Alexandra Hospital, Woollongabba, QLD: E. Walpole, D. Thompson; Royal Adelaide Hospital, Adelaide, SA: P. G. Gill, M. Bochner, J. Coventry, J. Kollias, P. Malycha, I. Olver; Royal Brisbane and Women's Hospital, Brisbane, QLD: M. Colosimo, R. Cheuk, L. Kenny, N. McCarthy, D. Wyld; Royal Hobart Hospital, Hobart, Tasmania: R. Young, R. Harrup, R. Kimber, R. Lowenthal; Royal Perth Hospital, Perth, WA: J. Trotter, E. Bayliss, A. Chan, D. Ransom; Sir Charles Gairdner Hospital, Perth, WA: M. Byrne, M. Buck, J. Dewar, A. Nowak, A. Powell, G. Van Hazel; Toowoomba Hospital, Toowoomba, QLD: E. A. Abdi, R. Brodribb, Z. Volobueva; Westmead Hospital, Sydney, NSW: P. Harnett, V. Ahern, H. Gurney, N. Wilcken.

New Zealand: Auckland Hospital, Auckland:V. J. Harvey, B. Evans, W. Jones, M. McCrystal, D. Porter, P. Thompson, M. Vaughan; Christchurch Hospital, Christchurch: D. Gibbs, C. Atkinson, R. Burcombe, B. Fitzharris, B. Hickey, M. Jeffery, B. Robinson; Dunedin Hospital, Dunedin: B. McLaren, S. Costello, J. North, D. Perez; Waikato Hospital, Hamilton: I. D. Campbell, L. Gilbert, R. Gannaway, M. Jameson, I. Kennedy, J. Long, G. Round, L. Spellman, D. Whittle, D. Woolerton.

Brazil: Hospital de Clinicas de Porto Alegre, Porto Alegre: C. Menke, J. Biazús, R. Cericatto, J. Cavalheiro, N. Xavier, A. Bittelbrunn, E. Rabin.

Chile: Chilean Cooperative Group for Oncologic Research, GOCCHI: J. Gutiérrez (Chairman), R. Arriagada (Scientific Adviser), L. Bronfman (Principal Investigator), M. Zuñiga (Data Manager); Clinica Las Condes, Santiago: J. Gutiérrez, J. C. Acevedo, S. Torres, A. León, E. Salazar; Hospital DIPRECA, Las Condes, Santiago: L. Soto Diaz, R. Duval, N. Oddeshede, M. C. Venti; Hospital San Juan de Dios, Santiago: K. Peña, L. Puente, V. Maidana; IRAM / Instituto de Radiomedicina, Vitacura, Santiago: R. Baeza, R. Arriagada, P. Olfos, J. Solé, E. Vinés, C. Mariani. Hungary: National Institute of Oncology, Budapest: I. Láng, E. Hitre, E. Szabó, Z. Horváth, E. Ganofszky, E. Juhos.

Italy: Centro di Riferimento Oncologico, Aviano: A. Veronesi, D. Crivellari, M. D. Magri, A. Buonadonna, F. Coran, E. Borsatti, E. Candiani, S. Massarut, M. Roncadin, M. Arcicasa, A. Carbone, T. Perin, A. Gloghini; Ospedali Riuniti di Bergamo, Bergamo: C. Tondini, R. Labianca, P. Poletti, A. Bettini; Ospedale degli Infermi, Biella: M. Clerico, M. Vincenti, A. Malossi, E. Seles, E. Perfetti, B. Sartorello; Spedali Civili, Brescia: E. Simoncini, G. Marini, P. Marpicati, R. Farfaglia, A. M. Bianchi, P. Grigolato, L. Lucini, P. Frata, A. Huscher, E. Micheletti, C. Fogazzi; U. O. Medicina Oncologica, Ospedale Capri, Ospedale Mirandola: F. Artioli, K. Cagossi, L. Scaltriti, E. Bandieri, L. Botticelli, G. Giovanardi; Ospedale di Cattolica 'Cervesi', Cattolica: A. Ravaioli, E. Pasquini, B. Rudnas; Ospedale Civile, Gorizia: L. Foghin; Ospedale 'A. Manzoni' Lecco, Lecco: M. Visini, L. Zavallone, G. Ucci; Istituto Europeo di Oncologia, Milano: M. Colleoni, G. Viale, P. Veronesi, G. Peruzzotti, L. Corsetto, R. Ghisini, G. Renne, A. Luini, L. Orlando, R. Torrisi, A. Rocca, T. De Pas, E. Munzone, V. Galimberti, S. Zurrida, M. Intra, F. Nolé, R. Orecchia, G. Martinelli, F. de Braud, A. Goldhirsch; Ospedale Infermi, Rimini: A. Ravaioli, L. Gianni.

Peru: Instituto de Enfermedades Neoplásicas, Lima: H. Gome.

Slovenia: Institute of Oncology, Ljubljana:T. Cufer, B. Pajk, J. Cervek.

South Africa: Groote Schuur Hospital and University of Cape Town, Cape Town: I. D. Werner, E. Murray, D. Govender, S. Dalvie, T. Erasmus, B. Robertson, B. Read,
E. Nel, J. Toop, N. Nedeva, E. Panieri; Sandton Oncology Centre, Johannesburg: D. Vorobiof, M. Chasen, G. McMichael, C. Mohammed. Local funding provided by the Cancer Association of South Africa

Sweden: West Swedish Breast Cancer Study Group: S. B. Holmberg; Sahlgrenska U Hospital, Moelndal: S. B. Holmberg, J. Mattsson; Boras Hospital, Boras; Karlstads Hospital, Karlstads: H. Sellström; Kungalvs Hospital, Kungalvs: B. Lindberg.

Switzerland: Swiss Group for Clinical Cancer Research (SAKK): A. Goldhirsch (up to January 2004), R. Herrmann (from June 2004): Kantonsspital Aarau, Zentrum f. Onkologie, Aarau: A. Schönenberger, W. Mingrone, Ch. Honegger, E. Bärtschi, M. Neter, M. Rederer, G. Schär; University Hospital Basel, Basel: C. Rochlitz, R. Herrmann, D. Oertli, E. Wight, H. Moch; Institute of Oncology of Southern Switzerland: Ospedale San Giovanni, Bellinzona: J. Bernier, L. Bronz, F. Cavalli, E. Gallerani, A. Richetti, A. Franzetti; Ospedale Regionale di Lugano (Civico \& Italiano), Lugano: M. Conti-Beltraminelli, M. Ghielmini, T. Gyr, S. Mauri, P. C. Saletti; Ospedale Regionale Beata Vergine, Mendrisio: A. Goldhirsch, O. Pagani, R. Graffeo, M. Locatelli, S. Longhi, P.C. Rey, M. Ruggeri; Ospedale Regionale La Carità, Locarno: E. Zucca, D. Wyss; Istituto Cantonale di Patologia, Locarno: L. Mazzucchelli, E. Pedrinis, T. Rusca; Inselspital, Berne: S. Aebi, M. F. Fey, M. Castiglione, M. Rabaglio; Kantonsspital Olten, Olten: S. Aebi, M. F. Fey, M. Zuber, G. Beck; Bürgerspital, Solothurn: S. Aebi, M. F. Fey, R. Schönenberger; Spital Thun-Simmental AG Thun: J.M. Lüthi, D. Rauch; Hôpital Cantonal Universitaire HCUG, Geneva: H. Bonnefoi; Rätisches Kantons- und Regionalspital, Chur: F. Egli, R. Steiner, P. Fehr; Centre Pluridisciplinaire d'Oncologie, Lausanne: L. Perey, P. de Grandi, W. Jeanneret, S. Leyvraz, J.-F. Delaloye; Kantonsspital St. Gallen, St. Gallen: B. Thürlimann, D. Köberle, F. Weisser, S., Mattmann, A. Müller, T. Cerny, B. Späti, M. Höfliger, G. Fürstenberger, B. Bolliger, C. Öhlschlegel, U. Lorenz, M. Bamert, J. Kehl-Blank, E. Vogel; Kantonales Spital Herisau, Herisau: B. Thürlimann, D. Hess, I. Senn, D. Köberle, A. Ehrsam, C. Nauer, C. Öhlschlegel, J. Kehl-Blank, E. Vogel; Stadtspital Triemli, Zürich: L. Widmer, M. Häfner; Universitätsspital Zürich, Zürich: B. C. Pestalozzi, M. Fehr, R. Caduff, Z. Varga, R. Trüb, D. Fink.

Swiss Private MDs: Private Praxis, Zürich: B. A. Bättig; Sonnenhof-Klinik Engeried, Berne: K. Buser; Frauenklinik Limmattalspital, Schlieren: N. Bürki; Private Praxis, Birsfelden: A. Dieterle; Private Praxis, Biel: L. Hasler; Private Praxis, Baar: M. Mannhart-Harms; Brust-Zentrum, Zürich: C. Rageth; Private Praxis, Berne: J. Richner; Private Praxis, Bellinzona: V. Spataro; Private Praxis, Winterthur: M. Umbricht.

United Kingdom: King's College Hospital/Breast Unit, London: P. Ellis, S. Harris, N. Akbar, H. McVicars, C. Lees, R. Raman, G. Crane.

\section{Danish Group (DBCG)}

H. T. Mouridsen; Rigshospitalet, Copenhagen: H. T. Mouridsen; Vejle Hospital, Vejle: E. Jakobsen; Odense University Hospital, Odense: S. Cold; KAS Herlev / Herlev University Hospital, Herlev: C. Kamby; Aalborg Sygehus Syd, Aalborg: M. Ewertz; Hilleroed Hospital, Hilleroed: P.M. Vestlev; Aarhus University Hospital, Aarhus: J. Andersen; Roskilde County Hospital, Roskilde: P. Grundtvig; Esbjerg Central Hospital, Esbjerg: E. Sandberg; Naestved Central Hospital, Naestved: P. Philip; Soenderborg Sygehus, Soenderborg: E. L. Madsen; Herning Central Hospital, Herning: K. A. Moeller; Viborg Sygehus, Viborg: V. Haahr; Landspitali University Hospital, Reykjavik, Iceland: J. Johansson.

\section{French Group (FNCLCC)}

Institut Bergonié, Bordeaux: L. Mauriac, M. Debled, P. Campo; Centre Hospitalier de la Côte Basque, Bayonne D. Larregain-Fournier, S. Remy, Centre Jean Perrin, Clermont-Ferrand: H. Auvray; Centre Georges François Leclerc, Dijon: C. De Gislain, F. Delille, M.-C. Porteret; Centre Oscar Lambret, Lille: V. Servent, M. Chapoutier; CHRU, Limoges: N. Tubiana-Mathieu, S. Lavau-Denes, P. Bosc; Centre Léon Bérard, Lyon: J. P. Guastalla, Th. Bachelot, C. Arbault; Centre Hospitalier Meaux, Meaux: G. Netter-Pinon; C.H.G. André Boulloche, Montbéliard: V. Perrin, A. Monnier, Y. Hammoud; Centre Paul Lamarque, Montpellier: G. Romieu, L. Culine, V. Pinosa; Clinique Francheville, Périgueux: L. Cany, C. Maguire; Hôpital de la Milétrie, Poitiers: A. Daban, M. Le Saux, C. Grandon; Centre Eugène Marquis, Rennes: P. Kerbrat, C. Catheline; Centre Henri Becquerel, Rouen: C. Veyret, E. Jugieau, V. Talon; Centre René Gauducheau, Saint-Herblain: A. Le Mevel, S. Maury; Centre Claudius Régaud, Toulouse: L. Gladieff, N. Lignon.

\section{North Yorkshire Group}

D. Dodwell; Harrogate District Hospital, Harrogate, North Yorkshire: D. Dodwell; Huddersfield Royal Infirmary, Huddersfield: J. Joffe; Castlehill Hospital, Hull: 
P. Drew; Airedale General Hospital, Keighley, W. Yorkshire: A. Nejim; Leeds General Infirmary, Leeds: D. Dodwell, K. Horgan; St. James's University Hospital, Leeds: M. Lansdown, T. Perren; Weston Park Hospital, Sheffield: R. E. Coleman.

\section{Independent Centers/Groups}

Argentina: Centro Oncológico Confidence, Buenos Aires: D. Campos; Hospital Allemán, Buenos Aires: F. Cóppola; Hospital Británico, Buenos Aires: J. Martinez; Hospital Evita, Buenos Aires: M. Freue; Hospital Posadas, Buenos Aires: C. Wainstein; Hospital Zubizarreta, Buenos Aires: A. Zori Comba; Instituto Dr. Estevez, Buenos Aires: E. Cazap; Instituto Oncológico Dr. Angel H. Roffo, Buenos Aires: E. Mickiewicz; Sanatorio Municipal Julio A. Mendez, Buenos Aires: L. Balbiani; Centro Privado de Ginecología, Córdoba: A. Osuna; Hospital Privado de Córdoba, Córdoba: E. Palazzo; Instituto Modelo de Ginecología y Obstetricia, Córdoba: M. de Romedis; Fundación Mainetti-Centro Oncológico de Excelencia, La Pllata: S. Cagnolati; Hospital Privado de la Comunidad, Mar del Plata: C. A. Delfino, G. Caccia; Escuela de Medicina Nuclear (COIR), Mendoza: R. L. de Angelis; Centro Oncológico de Rosario, Rosario: L. Fein, R. Sala; Hospital Provincial de Rosario, Rosario: C. Nassurdi, A. Colombo Berra; Clínica Especializada ISIS, Santa Fe: R. Viroglio, C. Blajman; Hospital Regional de Concepción, Tucumán: H. Requejo; Instituto de Maternidad y Ginecología Nuestra Señoras de las Mercedes, Tucumán: L. Silberman.

Australia: Flinders Medical Centre, Adelaide, SA: S. Birrell, M. Eaton, C. Hoffman; Queen Elizabeth Hospital, Adelaide, SA: V. Humeniuk; The Canberra Hospital, Canberra, ACT; P. Craft, R. Stuart-Harris, D. Yip; The Geelong Hospital, Geelong, VIC: R. Bell, F. Abell, M. Francis, J. Kiffer, R. Lynch, R. McLennan, K. White; Royal Melbourne Hospital, Melbourne, VIC: M. Green, R. Basser, J. Collins, R. De Boer, J. C. Din, N. Efe, S. T. Fan, G. Lindeman, S. Wong; Western General Hospital, Melbourne, VIC: M. Green, R. Basser, J. Collins, R. De Boer, J. C. Din, N. Efe, S. T. Fan, G. Lindeman, S. Wong; Newcastle Mater Hospital, Newcastle, NSW: J. Stewart, F. Abell, S. Ackland, A. Bonaventura; Royal Perth Hospital, Perth, WA: J. Trotter, E. Bayliss, A. Chan, D. Ransom, A. Redfern; St. George Hospital, Sydney, NSW: P. de Souza, M. Links; St. Vincent's Hospital, Sydney, NSW: D. Dalley, J. Grygiel, R. Ward; Murray Valley Private Hospital, Wodonga, VIC: C. Underhill, K. Clarke, C. Steer; Princess Alexandra Hospital, Woolloongabba, QLD: E. Walpole, D. Thompson.

Belgium: Institut Jules Bordet, Bruxelles: J. M. Nogaret; University Hospitals Leuven, Leuven: M.R. Christiaens, P. Neven, R. Paridaens, A. Smeets, I. Vergote, C. Weltens, H. Wildiers; Les Cliniques Saint-Joseph ASBL, Liège: C. Focan; Clinique du Parc Léopold, Bruxelles: L. Marcelis; C. H. Etterbeek - Ixelles, Bruxelles: J. P. Kains; Service d'Oncologie Clinique Notre-Dame, Charleroi: J.-L. Canon; C. H. U. André Vèsale, Montigny-Le Tilleul: D. Brohèe.

Canada: Cambridge Memorial Hospital, Cambridge: J. Gowing; CHUMCampus Notre-Dame, Montreal: L. Yelle; Hôpital Maisonneuve-Rosemont, Montreal: P. Dubé.

Chile: Fundacion Lopez Perez, Santiago: C. Vogel; Hospital Carlos Van Buren, Valparaiso: M. León Prieto.

Czech Republic: Institute of Oncology, Brno: K. Petrakova, M. Palacova, R. Demlova; Dept. of Clinical and Radiation Oncology, Ceske Budejovice: $\mathrm{H}$. Siffnerova, J. Fischer, I. Bustova; Centre of Breast Diseases, Prague: H. Kankova, M. Pintova; Institute of Radiation Oncology, Prague: P. Vitek; University Hospital, Prague: J. Abrahamova, D. Kordikova; University Hospital Prague: L. Petruzelka, E. Sedlackova, H. Honova.

Germany: Onkologische Gemeinschaftspraxis, Augsburg: B. Heinrich; Zentralklinikum/Frauenklinik, Augsburg: A. Wischnik; Universitätsklinikum Essen, Essen: C. Oberhoff, A. E. Schindler; Universitäts-Frauenklinik d. JLU Giessen, Giessen: K. Münstedt; Onkologische Gemeinschaftspraxis, Göttingen: D. Meyer; Martin-Luther-Universität Halle-Wittenberg, Halle: R. Grosse, H. Kölbl; Universitätskliniken des Saarlandes, Homburg: W. Schmidt, D. Mink; Universitäts-Frauenklinik und Poliklinik Universitätskrankenhaus Eppendorf, Hamburg: F. Jänicke; Kliniken d. Med. Hochschule, Frauenklinik, Hannover: H. J. Lück; Krankenanstalt Mutterhaus der Borromäerinnen, Trier: W. Dornoff; Gynäkologische Abteilung des St. Josefshospital, Wiesbaden: G. Hoffmann; Gynäkologische Abteilung d. Marienhospitals, Universität Witten-Herdecke, Witten: J. Hackmann, W. Bader.

Hungary: SZOTE Onkoterápiás Klinika, Szeged: Z. Kahan; BM Központi Kórház Budapest: G. Pajkos, K. Kristo; SOTE Radiológiai és Onkoterápiás Klinika, Budapest: M. Dank; Uzsoki Utcai Kórház, Budapest: T. Nagykalnai, L. Landherr; Almási Balogh Pál Kórház, Ózd: E. Kner; Területi Kórház Onkologia, Szentes: M. Kispál; Szent Borbála Kórház, Megyei Onkológiai Gondozó, Tatabánya: Á. Dani. Italy: Policlinico S. Orsola-Malpighi, Bologna: A. Martoni, C. Zamagni, S. Giaquinta, E. Piana; Ospedale S. Croce, Fano: R. Mattioli, L. Imperatori; Istituto
Clinica Humanitas, Milan/Rozzano: A. Santoro, C. Carnaghi, L. Rimassa; Azienda Ospedaliera San Filippo Neri, Rome: G. Gasparini, G. Sciarretta, A. Morabito; Az. Ospedaliera Treviglio-Caravaggio, Treviglio: S. Barni, M. Cazzaniga, M. Cabiddu; Policlinico Universitario (PUDG), Udine: F. Puglisi; Ospedale di Torrette, Ancona: R. Cellerino, S. Antognoli, F. Freddari; University of Cagliari, Policlinico Universitario, Cagliari: G. Mantovani, E. Massa, G. Astara; Ospedale Civile Feltre, Feltre: R. Segati; Istituto Nazionali Ricerca Cancro, Genova: R. Rosso, L. Del Mastro, M. Venturini, C. Bighin; Istituto Nazionale dei Tumori, Milano: E. Bajetta, N. Zilembo, D. Paleari, G. Procopio; Azienda Ospedaliera di Parma, Parma: S. Salvagni, M. A. Perrone , V. Franciosi; Azienda Ospedaliera 'S. Salvatore', Pesaro: G. Catalano, S. Luzi Fedeli; Azienda Ospedaliera 'Ospedale di Circolo e Fondazione Macchi'Varese: G. Pinotti, G. Giardina, I. Vallini; Universitiy of Cagliari, Policlinico Universitario, Cagliari: B. Massidda, M. T. Ionta, M. C. Deidda; Ospedale Maggiore, Lodi: G. Nalli, G. Sita; Policlinico Universitario, Palermo: I. Carreca, S. Cucciarré, D. Burgio; Ospedale Civile dello Spirito Santo, Pescara: M. Lombardo, G. Pandoli, P. Di Stefano; Azienda Ospedaliera Santa Maria Nuova, Reggio Emilia: C. Boni, G. Bisagni, M. C. Banzi, P. Linarello; Azienda Ospedaliera Desenzano del Garda, Manerbio: G. Colosini, A. Spasiano, A. Caldonazzo; Ospedale Civile ASL 20, Tortona: M. G. Pacquola. Netherlands: Ziekenhuis Leyenburg, Den Haag: H. P. Sleeboom; Catharina Ziekenhuis, Eindhoven: H. J. T. Rutten; St. Anna Ziekenhuis, Geldrop: E. J.T. Luiten; Tweesteden Ziekenhuis, Tilburg: H. Th. J. Roerdink; Maxima Medisch Centrum, Veldhoven: R. H. M. Roumen.

New Zealand: Dunedin Hospital, Dunedin: B. McLaren, S. Costello, J. North, D. Perez, K., Bayston, M. Pfieffer; Waikato Hospital, Hamilton: I. Kennedy, I. D. Campbell, L. Gilbert, R. Gannaway, M. Jameson, J. Long, G. Round, L. Spellman, D. Whittle, D. Woolerton.

Poland: Department of Oncology and Radiotherapy, Medical University of Gdansk, Gdansk: J. Jassem, M. Welnicka-Jaskiewicz, E. Senkus-Konefka, K. Matuszewska; Rydygier's Memorial Hospital, Krakow-Nova Huta: P. Koralewski, J. Pernal; Klinika Nowotworów Piersi i, Chirurgii Rekonstrukcyjnej-Warszawa, Warszawa: T. Pienkowski, E. Brewczynska, B. Bauer-Kosinska, R. SienkiewiczKozlowska, A. Jagiello-Gruszfeld, K. Sudol; Centrum Onkologii w Bydgoszczy, Oddzial Onkologii Klinicznej, Bydgoszcz: J. Tujakowski, B. Zurawski; Collegium Medicum Jagiellonian University, Krakow: J. Pawlega, E. Jablonska, A. Zygulska; Oddzial Kliniczny Onkologiczny, Centralnego Szpitala Klinicznego Wojskowej, Akademii Medycznej-Warszawa, Warszawa: M. Górnasiowa; Dolnoslaskie Centrum Onkologii, Wroclaw: E. Filypczyk-Cisarz, K. Pajak.

Portugal: Hospital de S. João, Porto: M. Damasceno; Instituto Português de Oncologia de Coimbra, Coimbra: J. Q. Albano; Hospital de Santa Maria, Lisboa: B. da Costa, L. Costa; Instituto Português de Oncologia de Lisboa, Lisboa: A. Henriques, H. Amaral; Hospital Geral de Santo António, Porto: F. Marques. Russia: Cancer Research Centre, Moscow: D. V. Komov, S. B. Polikarpova; Moscow Municipal Hospital No. 62, Moscow: A. N. Makhson, N. V. Zabaznyi; Moscow Research Institute of Diagnostics and Surgery, Moscow: E. K. Vozny, N. Y. Dobrovolskaya, S. Bolshakova, O. V. Yurgina; N. M. Emmanuel Institute of Biochemical Physics, Moscow: D. B. Korman, I. A. Maslova; N.N. Petrov Research Institute of Oncology, St. Petersburg: V. Semiglazov, V. Ivanov; Saint-Petersburg City Oncological Dispensary, St. Petersburg: G. Manikhas, G. Dolmatov. South Africa: Mamma Clinic, Tygerberg Hospital, Cape Town: J. Apffelstaedt; Southern Cross Hospital, Cape Town: D. Eedes; Pretoria Academic Hospital, Pretoria: C. Slabber; Pretoria East Hospital, Pretoria: M. A. Coccia-Portugal; Eastern Cape Oncology Centre, Port Elizabeth: K. Maart. Spain: Hospital Ruber Internacional, Madrid: J. E. Alés Martinez, P. Aramburo, R. Sánchez; Hospital Son Dureta, Palma del Mallorca: J. Rifa, J. Martin; Centro Oncológico Integral de Madrid (CONIM), Madrid: R. Pérez-Carrión, J. L. González Larriba, A. Cubillo; Hospital Universitario San Carlos, Madrid: M. M. Jiménez, A. Casado; Hospital Central de Asturias, Oviedo: J. Fra, J. M. Vieitez, E. Esteban, A. J. Lacave.

Switzerland: Universitätsfrauenklinik, Basel: E. Wight, S. Bartens, R. Decio, U. Güth; Klinik am Park, Zürich: U. Breitenstein.

Turkey: Ankara University Ibni Sina Hospital, Ankara: F. Icli, D. Dincol; Hacettepe University Oncology Institute, Ankara: E. Baltali, Y. Ozisik; Istanbul University Oncology Institute, Istanbul: E. Topuz, M. Basaran, A. Aydiner; Ege University Medical School, Izmir: E. Ozdedeli; 9 Eylul University Medical School, Izmir: O. Harmancioglu, A. U. Yilmaz.

United Kingdom: The Royal Marsden Hospital, London, Royal Marsden NHS Trust, Surrey: I. E. Smith; University of Dundee, Dundee: A. M. Thompson; Christie Hospital NHS Trust, South Manchester University Hospital Trust, Manchester: A. Wardley; Royal Bournemouth Hospital, Bournemouth: T. Hickish; North Middlesex Hospital, London: F. Neave. 
Uruguay: Hospital de Clinicas Dr. Manuel Quintela, Montevideo, Uruguay: G. Sabini.

Published: 26 May 2011

\section{References}

1. BIG 1-98 Collaborative Group: A comparison of letrozole and tamoxifen in postmenopausal women with early breast cancer. N Engl J Med 2005, 353:2747-2757.

2. Coates AS, Keshaviah A, Thürlimann B, Mouridsen H, Mauriac L, Forbes JF, Paridaens R, Castiglione-Gertsch M, Gelber RD, Colleoni M, Láng I, Del Mastro L, Smith I, Chirgwin J, Nogaret JM, Pienkowski T, Wardley A, Jacobsen EH, Price KN, Goldhirsch A: Five years of letrozole compared with tamoxifen as initial adjuvant therapy for postmenopausal women with endocrine-responsive early breast cancer: update of study BIG 1-98. J Clin Oncol 2007, 25:486-492.

3. Forbes JF, Cuzick J, Buzdar A, Howell A, Tobias JS, Baum M: Effect of anastrozole and tamoxifen as adjuvant treatment for early-stage breast cancer: 100-month analysis of the ATAC trial. Lancet Oncol 2008, 9:45-53.

4. Jakesz R, Jonat W, Gnant M, Mittlboeck M, Greil R, Tausch C, Hilfrich J, Kwasny W, Menzel C, Samonigg H, Seifert M, Gademann G, Kaufmann M, Wolfgang J; ABCSG and the GABG: Switching of postmenopausal women with endocrine-responsive early breast cancer to anastrozole after 2 years' adjuvant tamoxifen: combined results of ABCSG trial 8 and ARNO 95 trial. Lancet 2005, 366:455-462.

5. Kaufmann M, Jonat W, Hilfrich J, Eidtmann H, Gademann G, Zuna I, von Minckwitz G: Improved overall survival in postmenopausal women with early breast cancer after anastrozole initiated after treatment with tamoxifen compared with continued tamoxifen: the ARNO 95 study. J Clin Oncol 2007, 25:2664-2670.

6. Boccardo F: Switching to anastrozole after tamoxifen improves survival in postmenopausal women with breast cancer. Nat Clin Pract Oncol 2008, 5:76-77.

7. Coombes RC, Kilburn LS, Snowdon CF, Paridaens R, Coleman RE, Jones SE, Jassem J, Van de Velde CJ, Delozier T, Alvarez I, Del Mastro L, Ortmann O, Diedrich K, Coates AS, Bajetta E, Holmberg SB, Dodwell D, Mickiewicz E, Andersen J, Lønning PE, Cocconi G, Forbes J, Castiglione M, Stuart N, Stewart A, Fallowfield LJ, Bertelli G, Hall E, Bogle RG, Carpentieri M, Colajori E, Subar M, Ireland E, Bliss JM; Intergroup Exemestane Study: Survival and safety of exemestane versus tamoxifen after 2-3 years' tamoxifen treatment (Intergroup Exemestane Study): a randomised controlled trial. Lancet 2007, 369:559-70

8. Jonat W, Gnant M, Boccardo F, Kaufmann M, Rubagotti A, Zuna I, Greenwood $M$, Jakesz R: Effectiveness of switching from adjuvant tamoxifen to anastrozole in postmenopausal women with hormone-sensitive earlystage breast cancer: a meta-analysis. Lancet Oncol 2006, 7:991-996.

9. Dowsett M, Cuzick J, Ingle J, Coates A, Forbes J, Bliss J, Buyse M, Baum M, Buzdar A, Colleoni M, Coombes C, Snowdon C, Gnant M, Jakesz R, Kaufmann M, Boccardo F, Godwin J, Davies C, Peto R: Meta-analysis of breast cancer outcomes in adjuvant trials of aromatase inhibitors versus tamoxifen. J Clin Oncol 2010, 28:509-518.

10. Burstein $\mathrm{HJ}$, Prestrud AA, Seidenfeld J, Anderson $\mathrm{H}$, BuchholzTA, Davidson NE, Gelmon KE, Giordano SH, Hudis CA, Malin J, Mamounas EP, Rowden D, Solky AJ, Sowers MR, Stearns V, Winer EP, Somerfield MR, Griggs JJ; American Society of Clinical Oncology: American Society of Clinical Oncology clinical practice guideline: update on adjuvant endocrine therapy for women with hormone receptor-positive breast cancer. J Clin Oncol 2010, 28:3784-3796.

11. Goldhirsch A, Ingle JN, Gelber RD, Coates AS, Thürlimann B, Senn HJ; Panel members: Thresholds for therapies: highlights of the St. Gallen International Expert Consensus on the primary therapy of early breast cancer 2009. Ann Oncol 2009, 20:1319-1329.

12. BIG 1-98 Collaborative Group: Letrozole therapy alone or in sequence with tamoxifen in women with breast cancer. N Engl J Med 2009, 361:766-776

13. Colleoni M, Giobbie-Hurder A, Regan MM, Thürlimann B, Mouridsen $H$, Mauriac L, Forbes JF, Paridaens R, Láng I, Smith I, Chirgwin J, Pienkowski T, Wardley A, Price KN, Gelber RD, Coates AS, Goldhirsch A: Analyses adjusting for selective crossover show improved overall survival with adjuvant letrozole compared with tamoxifen in the BIG 1-98 study. J Clin Oncol 2011, 29:1117-1124

14. Giobbie-Hurder A, Price KN, Gelber RD for the International Breast Cancer Study Group and BIG 1-98 Collaborative Group: Design, conduct, and analyses of Breast International Group (BIG) 1-98: a randomized, doubleblind, phase-III study comparing letrozole and tamoxifen as adjuvant endocrine therapy for postmenopausal women with receptor-positive, early breast cancer. Clinical Trials 2009, 6:272-286.

15. Koeberle D, Thuerlimann B: Letrozole as upfront endocrine therapy for postmenopausal women with hormone-sensitive breast cancer: BIG 1-98. Breast Cancer Res Treat 2007, 105:55-66.

16. Finkelstein DM, Schoenfeld DA: Correcting for discretionary treatment crossover in an analysis of survival in the Breast International Group BIG 1-98 Trial by using the inverse probability of censoring weighted method. J Clin Oncol 2011, 29:1093-1095.

17. Robins JM, Finkelstein DM: Correcting for noncompliance and dependent censoring in an AIDS clinical trial with inverse probability of censoring weighted (IPCW) log rank tests. Biometrics 2000, 56:779-788.

18. Mauriac L, Keshaviah A, Debled M, Mouridsen H, Forbes JF, Thürlimann B, Paridaens R, Monnier A, Láng I, Wardley A, Nogaret J-M, Gelber RD, Castiglione-Gertsch M, Price KN, Coates AS, Smith I, Viale G, Rabaglio M, Zabaznyi N, Goldhirsh A, for the BIG 1-98 Collaborative and the International Breast Cancer Study Groups: Predictors of early relapse in postmenopausal women with hormone receptor positive breast cancer in the BIG 1-98 trial. Ann Oncol 2007, 18:859-867.

19. Viale G, Regan MM, Maiorano E, Mastropasqua MG, Dell'Orto P, Rasmussen BB, Raffoul J, Neven P, Orosz Z, Braye S, Oehlschlegel C, Thürlimann B, Gelber RD, Castiglione-Gertsch M, Price KN, Goldhirsch A, Gusterson BA, Coates AS: Prognostic and predictive value of centrally reviewed expression of estrogen and progesterone receptors in a randomized trial comparing letrozole and tamoxifen adjuvant therapy for postmenopausal women with early breast cancer: BIG 1-98. J Clin Onco/ 2007, 25:3846-3852.

20. Lazar AA, Cole BF, Bonetti M, Gelber RD: Evaluation of treatment-effect heterogeneity using biomarkers measured on a continuous scale: subpopulation treatment effect pattern plot. J Clin Oncol 2010, 28:4539-4544

21. Rasmussen BB, Regan MM, Lykkesfeldt AE, Dell'Orto P, Del Curto B, Henriksen KL, Mastropasqua MG, Price KN, Méry E, Lacroix-Triki M, Braye S, Altermatt HJ, Gelber RD, Castiglione-Gertsch M, Goldhirsch, A, Gusterson BA, Thürlimann B, Coates AS, Viale G, for the BIG 1-98 Collaborative and the International Breast Cancer Study Groups: Adjuvant letrozole vs. tamoxifen according to centrally-assessed ERBB2 status for postmenopausal women with endocrine-responsive early breast cancer: supplementary results from the BIG 1-98 randomised trial. Lancet Oncol 2009, 9:23-28.

22. Viale G, Giobbie-Hurder A, Regan MM, Coates AS, Mastropasqua MG, Dell'Orto P, Maiorano E, MacGrogan G, Braye SG, Öhlschlegel C, Neven P, Orosz Z, Olszewski WP, Knox F, Thürlimann B, Price KN, Castiglione-Gertsch M, Gelber RD, Gusterson BA, Goldhirsch A: Prognostic and predictive value of centrally reviewed Ki- 67 labeling index in postmenopausal women with endocrine-responsive breast cancer: results from Breast International Group Trial 1-98 comparing adjuvant tamoxifen with letrozole. J Clin Oncol 2008, 26:5569-5575.

23. Viale G, Regan MM, Dell'orto P, Mastropasqua MG, Maiorano E, Rasmussen BB, Macgrogan G, Forbes JF, Paridaens RJ, Colleoni M, Láng I, Thürlimann B, Mouridsen H, Mauriac L, Gelber RD, Price KN, Goldhirsch A, Gusterson BA, Coates AS; for the BIG 1-98 Collaborative and International Breast Cancer Study Groups: Which patients benefit most from adjuvant aromatase inhibitors? Results using a composite measure of prognostic risk in the BIG 1-98 randomised trial. Ann Oncol 2011 Feb 18. [Epub ahead of print].

24. Leyland-Jones B, Regan MM, Bouzyk M, Kammler R, Tang W, Pagani O, Maibach R, Dell'Orto P, Thürlimann B, Price KN, Viale G, for the BIG 1-98 Collaborative Group and IBCSG: Outcome according to CYP2D6 genotype among postmenopausal women with endocrine-responsive early invasive breast cancer randomized in the BIG 1-98 trial. Cancer Res 2010, 70 (24 suppl):78s. Abstract S1-8.

25. Northrop Grumman Corporation: Medical Dictionary for Regulatory Activities (MedDRA) Maintenance and Support Services Organization (MSSO) homepage [http://www.meddramsso.com]

26. Mouridsen $\mathrm{H}$, Keshaviah A, Coates AS, Rabaglio M, Castiglione-Gertsch M, Sun Z, Thürlimann B, Mauriac L, Forbes JF, Paridaens R, Gelber RD, Colleoni M, Smith I, Price KN, Goldhirsch A: Cardiovascular adverse events during adjuvant endocrine therapy for early breast cancer using letrozole or tamoxifen: safety analysis of trial BIG 1-98. J Clin Oncol 2007, 25:5715-5722.

27. Rabaglio M, Sun Z, Price KN, Castiglione-Gertsch M, Hawle H, Thürlimann B, Mouridsen H, Campone M, Forbes JF, Paridaens RJ, Colleoni M, Pienkowski T, 
Nogaret JM, Láng I, Smith I, Gelber RD, Goldhirsch A, Coates AS, for the BIG 1-98 Collaborative and International Breast Cancer Study Groups: Bone fractures among postmenopausal patients with endocrine-responsive early breast cancer treated with 5 years of letrozole or tamoxifen in the BIG 1-98 trial. Ann Oncol 2009, 20:1489-1498.

28. Crivellari D, Sun Z, Coates AS, Price KN, Thürlimann B, Mouridsen H, Mauriac L, Forbes JF, Paridaens RJ, Castiglione-Gertsch M, Gelber RD, Colleoni M, Láng I, Del Mastro L, Gladieff L, Rabaglio M, Smith IE, Chirgwin JH, Goldhirsch A: Letrozole compared with tamoxifen for elderly patients with endocrineresponsive early breast cancer: the BIG 1-98 trial. J Clin Oncol 2008, 26:1972-1979.

29. Ewer MS, Glück S: A women's heart: the impact of adjuvant endocrine therapy on cardiovascular health. Cancer 2009, 115:1813-1826.

30. Perez EA: The balance between risks and benefits: long-term use of aromatase inhibitors. Eur J Cancer 2006, 4 (suppl):16-25.

31. Phillips KA, Ribi K, Sun Z, Stephens A, Thompson A, Harvey V, Thürlimann B, Cardoso F, Pagani O, Coates AS, Goldhirsch A, Price KN, Gelber RD, Bernhard J:
Cognitive function in postmenopausal women receiving adjuvant letrozole or tamoxifen for breast cancer in the BIG 1-98 randomized trial. Breast 2010, 19:388-395.

32. Phillips KA, Aldridge J, Ribi K, Sun Z, Thompson A, Harvey V, Thürlimann B, Cardoso F, Pagani O, Coates AS, Goldhirsch A, Price KN, Gelber RD, Bernhard J: Cognitive function in postmenopausal breast cancer patients one year after completing adjuvant endocrine therapy. Breast Cancer Res Treat 2011, 126:221-226.

\section{doi:10.1186/bcr2837}

Cite this article as: Regan MM, et al.: Interpreting Breast International Group (BIG) 1-98: a randomized, double-blind, phase III trial comparing letrozole and tamoxifen as adjuvant endocrine therapy for postmenopausal women with hormone receptor-positive, early breast cancer. Breast Cancer Research 2011, 13:209. 